ZOOLOGIA 31 (4): 393-399, August, 2014

http://dx.doi.org/10.1590/S1984-46702014000400011

\title{
Taxonomic status and redescription of Flectonotus ulei (Anura: Hemiphractidae), with a key for the species of Fritziana
}

\author{
Manuella Folly,4, Fabio Hepp², Sergio P. Carvalho-e-Silva \& William E. Duellman³
}

\author{
${ }^{1}$ Instituto de Biologia, Universidade Federal do Rio de Janeiro. Ilha do Fundão, 21941-590 Rio de Janeiro, RJ, Brazil. \\ 2 Departamento de Vertebrados, Museu Nacional, Universidade Federal do Rio de Janeiro. 20940-040 Rio de Janeiro, RJ, Brazil. \\ ${ }^{3}$ Division of Herpetology, Biodiversity Institute, University of Kansas. 66045-7561 Lawrence, KS, USA. \\ ${ }^{4}$ Corresponding author. E-mail: manuellafolly88@gmail.com
}

\begin{abstract}
Based on preserved specimens from the states of São Paulo and Rio de Janeiro, Flectonotus ulei MirandaRibeiro, 1926 is resurrected from its synonymy with Flectonotus fissilis (Miranda-Ribeiro, 1920) and is redescribed. Analysis of osteological characters and brood pouch structure confirms that $F$. ulei belongs to Fritziana. The species is small for the genus (snout-vent length in males, 19.2-26.9 mm, $\mathrm{m}=2$; in females, 20.3-21 mm, $\mathrm{n}=4$ ) and was found in bromeliads. Flectonotus ulei is characterized by dorsal pattern consisting of interorbital pentagon or hexagon-shaped mark delimited by heavy dark line, diameter of tympanum smaller than that of disc of third digit, and a brood pouch covering the eggs dorsally except for a narrow longitudinal slit; eggs arranged in rosette.
\end{abstract}

KEY WORDS. Amphibia; Atlantic Rain Forest; Bromeliad breeder; Hemiphractidae; Southeastern Brazil; taxonomy.

The Hemiphractidae genera Flectonotus Miranda-Ribeiro, 1926 and Fritziana Mello-Leitão, 1937 have a confused taxonomic history. Firstly, BoetTger (1893) described Nototrema pygmeum from northern Venezuela; Boulenger (1895) and WANDOLLECK (1907) described two similar species as members of the genus Hyla from southeastern Brazil, $H$. goeldii and $H$. ohausi respectively. MiRAnda-RiberiRo (1920) described another species from southeastern Brazil and placed it in a new genus, Coelonotus fissilis, and transfered $H$. goeldii and $H$. ohausi to a new genus, Fritzia. Miranda-Ribeiro (1926) proposed a new generic name, Flectonotus, for Nototrema pygmeum, in which he named a new species, Flectonotus ulei. Mello-Leitão (1937) noted that Fritzia Miranda-Ribeiro, 1926 was preoccupied by Fritzia Cambridge (Arachnida) and proposed Fritziana as a substitute name. The name Coelonotus Miranda-Ribeiro, 1920, was preoccupied by Coelonotus Peters (Pisces), and was replaced by Nototheca by BoKermann (1950). In the same paper, Bokermann included Gastrotheca fitzgeraldi Parker (1934) in the genus Nototheca. LuTz (1954) considered the differences between Fritzia goeldii (= Fritziana goeldii), Nototheca fissilis, and Flectonotus ulei to be insufficient for generic recognition, but placed only $F$. goeldii in the genus Flectonotus. Furthermore, without justification, BoKermanN (1966) allocated N. fissilis to Flectonotus together with F. pygmaeus, placed Flectonotus goeldii in Fritziana, and synonymized Flectonotus ulei with F. fissilis. Duellman \& Gray (1983) considered $F$. fissilis in the genus Fritziana with $F$. goeldii and $F$. ohausi and recognized Flectonotus only for $F$. pygmaeus and $N$. fitzgeraldi (these authors did not examine specimens of $F$. ulei). Weygoldt \& Carvalho-e-Silva's (1991) reinterpretation of
Duellman \& Gray's phylogenetic arrangement resulted in them synonymizing Fritziana with Flectonotus. Later, both genera were revealed to be monophyletic and were formally recognized (Duellman et al. 2011).

As currently recognized, Fritziana has three species distributed in southern and southeastern Brazil: F. fissilis, F. goeldii, and F. ohausi (Duellman et al. 2011). According to Duellman \& Gray (1983), frogs in this genus have large nasals that are anteriorly nearly in contact with the sphenethmoid; skin folds of the brood pouch bordering eggs laterally (extending dorsally in F. fissilis); developing embryos with two pairs of gills, each gill with a single stalk; and larvae with keratinized beaks and small papillae but no denticles.

An adult female with eggs on its back (ZUFRJ 13337), and which was found in Nova Friburgo municipality (typelocality), does not fit the description of any species other than Flectonotus ulei. Miranda-Ribeiro (1926) described this species based on one female and considered it most similar to Flectonotus pygmaeus. Therefore, herein we revalidate and redescribe F. ulei, provide a new diagnosis for it, and compare it with congeners.

\section{MATERIAL AND METHODS}

The Fritziana specimens examined by us are deposited in the following Herpetological collections: MNRJ (Museu Nacional, Rio de Janeiro, RJ, Brasil), MZUSP (Museu de Zoologia, Universidade de São Paulo, SP, Brasil), UNIRIO (Universidade Federal do Estado do Rio de Janeiro), ZUFRJ (Departamento de

2014 Sociedade Brasileira de Zoologia | www.sbzoologia.org.br | www.scielo.br/zool All content of the journal, except where identified, is licensed under a Creative Commons attribution-type BY-NC. 
Zoologia, Universidade Federal do Rio de Janeiro). Specimens examined of species other than F. ulei are listed in Appendix 1.

Abbreviations of the measurements of adults are: SVL (snout-vent length, distance from the tip of the snout to cloaca); HL (head length; dorsal distance from the tip of the snout to the tympanum); HW (head width; dorsal distance between the tympani); NSD (nostril-tip of snout distance, interval between the tip of the snout to the nostril); IND (internarial distance, interval between the nostrils); IOD (interorbital distance, interval between the inner edge of the orbits); ED (eye diameter, longitudinal distance from the beginning to the end of the eye); END (eye-nostril distance, interval between the edge of the eye and the nostril); TYD (tympanum diameter, width of the tympanum); ARL (arm length, distance from the shoulder to the elbow); FRL (forearm length, distance from the elbow to the wrist); HNL (hand length, distance from the from base of palmar tubercle to tip of finger three); F3L (finger 3 length, distance from base of finger to tip of the adhesive disc); DD3 (diameter of adhesive disc on third finger, width of the third finger); THL (thigh length, distance from the cloaca to the knee); TBL (tibia length, distance from the ankle to the knee); FL (foot length, distance between the heel of the longest toe); and T4L (toe length, distance from the base of toe to tip of adhesive disc). The measurements (in millimeters) follow: Duellman (1970) with SVL, HL, HW, ED, IOD, IND, TYD and TBL; Heyer et al. (1990) with ARL, FRL, HNL and THL; and NAPOLI \& CARAMASCHI (1998) with NSD, END, FL, and DD3. We used a digital caliper of $0.01 \mathrm{~mm}$ of precision and an ocular micrometer in a Leica MZ-6 stereomicroscope.

The nomenclature for the shape of tubercles follows Duellman (1970) and the nomenclature of the position of tubercles follows Targino \& Carvalho-e-Silva (2008). The webbing formula follows SAVAGE \& HEyer (1967) with subsequent modifications from Myers \& Duellman (1982). Males were identified by presence of vocal slits and females by absence of them. Additionally some females were promptly recognized by presence of dorsal pouch. Radiographs were obtained using a Faxitron MX-20 specimen radiography system ( $\mathrm{kV} \mathrm{25;} 19 \mathrm{sec}$ ). Images were captured with software Faxitron SR DCF 3.1.8b and edited with Adobe Photoshop CS4.

\section{TAXONOMY}

A brooding female with eleven eggs (ZUFRJ 13347) was found in the municipality of Nova Friburgo (22 $20^{\prime} 24.0^{\prime \prime} S$ $042^{\circ} 26^{\prime} 50.6^{\prime \prime} \mathrm{W}, 1316 \mathrm{~m}$ a.s.l.). It has a pentagon-shaped mark on the top of the head, and the eggs are arranged in a rosette in a brood pouch that opens longitudinally, as described and illustrated by Miranda-Ribeiro (1926). Other specimens examined from the same (MNRJ 0271) and other localities (MZUSP 128088, A-75903, A-75844, A-128089) from various collections (see Appendix 1) also show these features and are identified as F. ulei.
Radiographs show that all species have large nasals that are narrowly separated from the maxillae and premaxillae (Figs 1-4). Large nasals that differ from the small nasals of Flectonotus have been proposed as diagnostic characters of Fritziana, (see fig. 2 in Duellman \& Gray 1983, Duellman et al. 2011). The size and disposition of the nasals confirm that Flectonotus ulei belongs to the genus Fritziana. In addition to the osteological characters, females of Fritziana ulei (MNRJ 0271 and ZUFRJ 13347) have dorsolateral folds of the brood pouch covering the eggs dorsally, but not adhering mid-dorsally over the eggs forming an enclosed pouch, as it occurs in females of Flectonotus (Duellman \& Gray 1983, Duellman et al. 2011).

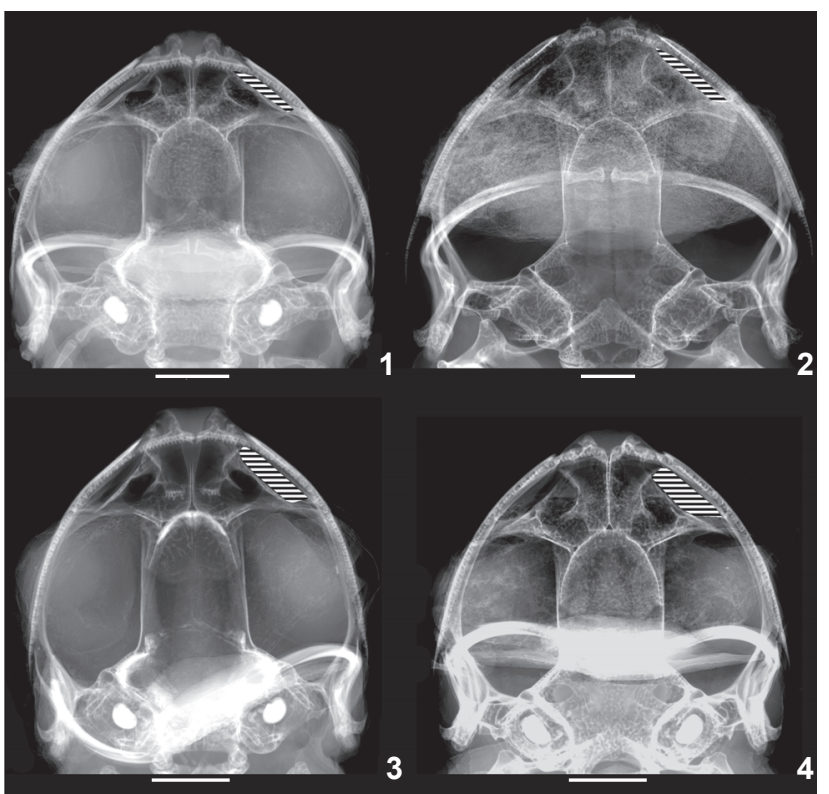

Figures 1-4. X-ray of the four Fritziana species: (1) F. fissilis (ZUFRJ 14093); (2) F. goeldii (UNIRIO 2538); (3) F. ohausi (ZUFRJ 14094); (4) F. ulei (ZUFRJ 13337). Note the narrow spaces (hatched) between the nasals and maxillae (see text). Mouths of the four specimens are opened. Scale bars $=2 \mathrm{~cm}$.

\section{Fritziana ulei (Miranda-Ribeiro, 1926) reval., comb. nov.}

\section{Figs $5-15$}

Flectonotus ulei Miranda-Ribeiro, 1926: 109.

Flectonotus fissilis: (part), Bokermann 1966: 41.

Holotype (MNRJ 0271) by monotypy, female from the municipality of Nova Friburgo, state of Rio de Janeiro, Brazil, collected by Ernesto Ule, without date (Figs 5-8). BoKermanN (1950) considered the specimen MNRJ A.271 (=MNRJ 0271) as "the type" of the species. In fact this specimen is the only one in the herpetological collection of the MNRJ that fits the lo- 
cality data given by Miranda-Ribeiro (1926) (locality and collector). Additionally the original voucher records of the specimen are marked "type M.Rib." The morphological features of MNRJ 0271, such as the shape of the interorbital pentagon and the position and number of the eggs, correspond exactly with the drawing in the original description.

Diagnosis. Members of the genus Fritziana can be recognized by having large nasals nearly in anterior contact with the sphenethmoid, and folds in the skin of the brood pouch bordering eggs laterally. They can be further diagnosed by the following characteristics: Interorbital bronze pentagon/hexagon-shaped mark (in life with a dark border; Fig 9); nostrils narrowly separated (IND/IOD = 0.6); diameter of tympanum less than diameter of disc on third finger; subarticular tubercles not bifid (Figs 7 and 14); venter uniformly beige; lateral folds of brood pouch covering eggs dorsally with small longitudinal slit middorsally; eggs arranged in rosette (i.e., some eggs located centrally and bordered by others; Figs 5, 9, and 10).

Redescription of the holotype. Dorsolateral folds of dorsal pouch in females extending dorsally, leaving only a slit medially. Eggs arranged in a rosette pattern with one central egg surrounded by six eggs (Fig. 5). Skin on dorsal surfaces mostly smooth, finely tuberculate on head. Snout-vent length $20.3 \mathrm{~mm}$, head slightly wider $(\mathrm{HW}=4.6 \mathrm{~mm})$ than long $(\mathrm{HL}=$ $4.3 \mathrm{~mm})$, length equaling $88 \%$ of the width $(\mathrm{HL} / \mathrm{HW}=0.9)$. Snout acuminate in dorsal view, protruding in lateral view; tip of the snout with sharp vertical keel (Fig. 8). Nostrils oval, lateral, closer to the tip of snout $(\mathrm{NSD}=1.0 \mathrm{~mm}$ ) than to anterior corner of orbit; internasal distance (IND $=1.7 \mathrm{~mm}$ and $\mathrm{IOD}=$ $2.4 \mathrm{~mm}$ ) equivalent to $71 \%$ of interorbital distance (IND/IOD $=0.71)$ and $37 \%$ of head width $(\mathrm{IND} / \mathrm{HW}=0.37)$. Eye diameter $(\mathrm{ED}=3.5 \mathrm{~mm})$ equivalent to $81 \%$ of head length $(\mathrm{ED} / \mathrm{HL}=$ 0.81). Canthus rostralis distinct, rounded; loreal region concave. Tongue oval. Vomerine teeth between choanal openings. Tympanum distinct, small (TYD $=0.8 \mathrm{~mm}), 24 \%$ of the diameter of the eye and smaller than the diameter of disc on third finger (TYD/DD3 = 0.84). Supratympanic fold well developed, extending from eye to insertion of arm. Outer margins of hand, arm, thigh, tibia, knee and tarsus are crenulate. Arms long and robust; lengths of fingers I < II < IV < III; discs on fingers well developed; fingers not webbed; subarticular tubercles large, not bifid; supranumerary tubercles small; palmar tubercles large; number of subarticular and supernumerary tubercles on fingers I, II, III, and IV are 3, 2, 4, and 2, respectively. Fingers I, II and III have subarticular and supernumerary tubercles and the finger IV have only subarticular tubercles. Legs large; toe lengths I $<$ II $<$ V $<$ III $<$ IV; vestigial webbing between toes I - II; webbing formula, I - II $2-3$ III $2^{1 / 2}-3 \frac{1}{2}$ IV $3 \frac{1}{2} 2-2 \frac{1}{2} \mathrm{~V}$. The number of tubercle for the toes I, II, III, IV, and V are 3, 3, 5, 6, and 2, respectively, including subarticular and supernumerary tubercles; two palmar tubercles. Granular venter.

Color in preservative (70\% ethanol). Dorsal pattern characterized by interorbital hexagon-shaped mark, beige, delimi-

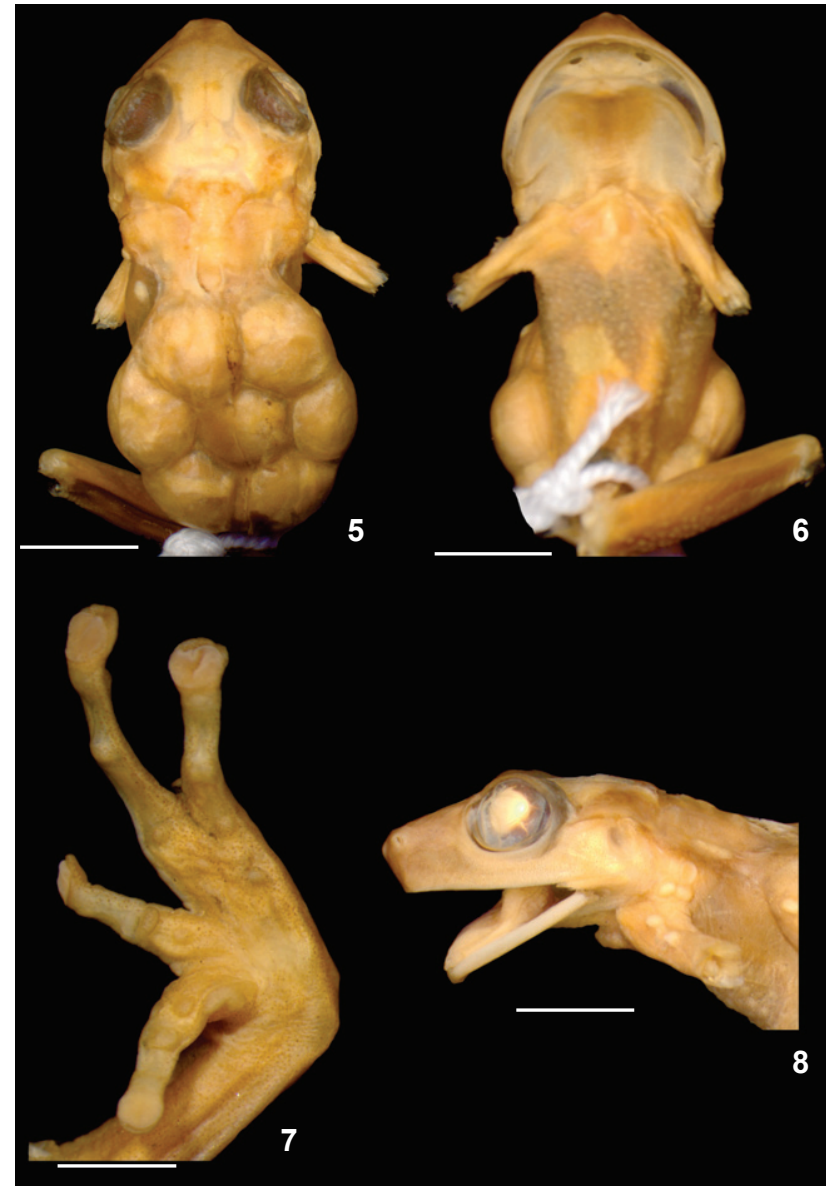

Figures 5-8. Holotype of Fritziana ulei MNRJ 0271: (5) Dorsal and (6) ventral views; (7) ventral view of left hand; (8) lateral view of head. Scale bars: 5-6 $=10 \mathrm{~mm}, 7-8=1 \mathrm{~mm}$.

ted by strong dark line. Posterior edge of the hexagon reaches beyond level of eye, reaching tympanum level. Hexagon top is near to tip of nose. Dark dorsal discs. Thigh and tibia beige. Arms with same pattern as legs. Venter beige.

Measurements of holotype. SVL 20.3, HL 4.3, HW 4.6, NSD 0.99, IND 1.7, IOD 2.4, ED 3.5, END 1.7, TYD 0.8, ARL 3.7, FRL 3.8, HNL 5.6, F3L 4.6, DD31.0, THL 10.6, TBL 11.6, FL 13.0, T4L 8.0.

Color pattern of recently collected specimens. The dorsal pattern consists of interorbital pentagon/hexagon-shaped mark delimited by prominent dark line; mark beige in preservative and bronze in life (Figs 9, 10 and 11). Dorsal surfaces of discs on fingers can be dark black. In preservative thighs, shanks, and forearms beige with brown spots in living individuals. Dark brown line extending from orbit across supratympanic to just posterior to arm insertion.

Variation. Males and females approximately the same size (Table I) and with same dorsal pattern. Males with snout-vent 


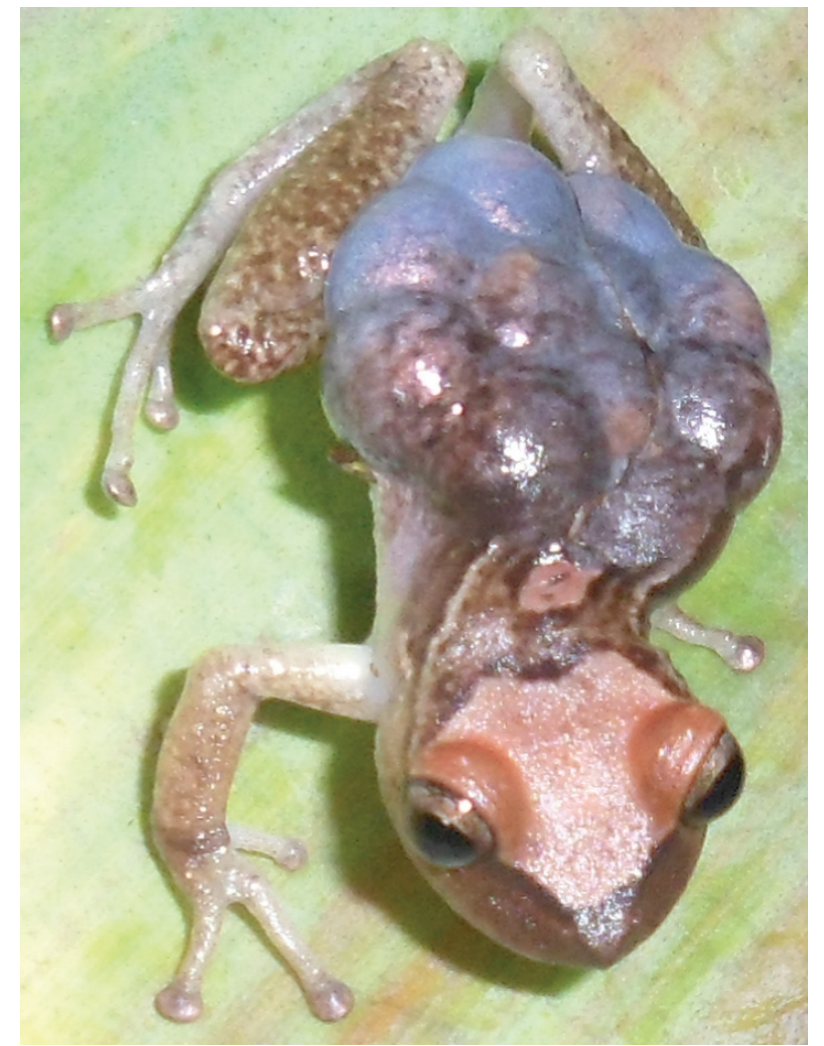

Figure 9. Female Fritziana ulei (ZUFRJ 13337). Note the dorsal coloration pattern and the arrangement of the eggs.

length 19.2 to 26.9 (SVL: $\bar{x}=22.7 \pm 3.6$ ), head almost as wide (HW: $\bar{x}=8.4 \pm 1.7$ ) as long (HL: $\bar{x}=7.9 \pm 1.4$ ), length $89 \%$ of width (HL/HW: $\bar{x}=0.9 \pm 0.0)$. Internasal distance (IND: $\bar{x}=1.6$ \pm 0.3 and IOD: $\bar{x}=2.7 \pm 0.5) 58 \%$ of interorbital distance (IND/ IOD: $\bar{x}=0.6 \pm 0.1$ ) and $22 \%$ of head width (IND/HW: $\bar{x}=0.2 \pm$ 0.1 ). Eyes large, (ED: $\bar{x}=4.0 \pm 0.4 \mathrm{~mm}$ ) $59 \%$ of head length (ED/HL: $\bar{x}=0.6 \pm 0.1)$. Male vocal sac single, median, and subgular. Tympanum distinct and small (TYD: $\bar{x}=1.1 \pm 0.1$ ), more than one quarter of eye diameter, corresponding to $26 \%$ of eye diameter (TYD/ED: $\bar{x}=0.3 \pm 0.1$ ), and smaller than diameter of digit on third finger (TYD/DD3: $\bar{x}=0.8 \pm 0.1$ ). Number of subarticular and supernumerary tubercles per finger very variable in males and females, and may be: $\mathrm{I}-3,5$ or 8 ; II -2 , 3,4 or 5 ; III $-4,6$ or 7 . Number of tubercles per toe very variable in males and females, including subarticular and supernumerary, and may be: I -3 or 5 ; II -3 or 4 ; III $-4,5$ or 7 ; IV 6 or 7.

Comparisons with other species. Fritziana ulei has an interorbital bronze pentagon/hexagon-shaped mark bordered by black, whereas $F$. fissilis has an interorbital brown hourglass/ trapezium-shaped mark, extending to the sacral region; F. goeldii has a brown interorbital hourglass-shaped mark extending to middle of body; Fritziana ohausi has a marbled dorsal and lat-
Table I. Measurements (in millimeters) of Fritziana ulei. Abbreviations of the measurements are defined in the Material and Methods. The mean \pm standard deviation is followed by the (range).

\begin{tabular}{ccc}
\hline Measurements & Females $(n=2)$ & Males $(\mathrm{n}=3)$ \\
\hline SVL & $20.3-21.0$ & $22.7 \pm 3.6(19.2-26.9)$ \\
HL & $4.3-7.0$ & $7.9 \pm 1.4(6.3-9.0)$ \\
HW & $4.6-7.9$ & $8.4 \pm 1.7(6.5-10.4)$ \\
ED & $3.3-3.5$ & $4.0 \pm 0.4(3.6-4.3)$ \\
IOD & $2.4-3.0$ & $2.7 \pm 0.5(2.2-3.2)$ \\
IND & $0.8-0.9$ & $1.6 \pm 0.3(1.3-1.9)$ \\
TYD & $0.8-0.9$ & $1.1 \pm 0.4(0.7-1.6)$ \\
TBL & $11.0-11.6$ & $12.4 \pm 1.5(11.1-13.9)$ \\
ARL & $3.6-6.3$ & $6.5 \pm 1.2(5.4-7.7)$ \\
FRL & $3.8-4.7$ & $4.5 \pm 5.6(3.8-5.1)$ \\
HNL & $5.6-6.5$ & $6.7 \pm 1.2(5.4-8.1)$ \\
THL & $9.6-10.5$ & $10.8 \pm 1.0(10.0-12.2)$ \\
END & $1.6-2.2$ & $1.9 \pm 0.4(1.5-2.3)$ \\
NSD & $0.9-0.9$ & $1.0 \pm 0.2(0.9-1.3)$ \\
FL & $13.0-15.0$ & $16.6 \pm 2.8(14.1-19.5)$ \\
F3L & $4.6-5.5$ & $5.6 \pm 1.2(4.3-6.5)$ \\
DD3 & $1.0-1.1$ & $1.3 \pm 0.4(1.0-1.8)$ \\
T4L & $8.0-8.2$ & $8.6 \pm 2.1(6.2-10.0)$ \\
\hline
\end{tabular}

eral pattern, and the interorbital brown ob triangle-shaped mark is connected to two stripes, which can be long and divergent, extending to the sacral region, short and divergent, or short and fused. As in F. goeldii and F. ohausi, F. ulei has normalshaped subarticular and supernumerary tubercles and different from F. fissilis, which has bifid distal subarticular tubercles on the fingers. The venter is uniformly beige in $F$. ulei and $F$. fissilis and different from $F$. goeldii and F. ohausi, in which brown small flecks are present on the venter. In F. ulei, F. ohausi, and $F$. goeldii the diameter of the tympanum is less than the width of the disc on the third finger, whereas in F. fissilis the diameter of the tympanum is equal or larger than that of the disc. The brood pouch of $F$. ulei extends dorsally and encapsulates the eggs, resulting in a median longitudinal slit similar to $F$. fissilis. The eggs of $F$. ulei are organized symmetrically, giving a rosette shape to the clutch, differing from $F$. fissilis by having eggs not organized symmetrically. In F. goeldii and F. ohausi the dorsolateral folds are low so as to leave the eggs exposed dorsally.

Natural history. One individual (ZUFRJ 13347), a female carrying 11 eggs, was found in a terrestrial bromeliad in the garden of a house. The house is located in a disturbed area in the mountain at about $1,300 \mathrm{~m}$, in Lumiar $\left(22^{\circ} 20^{\prime} 30.43^{\prime \prime} \mathrm{S}\right.$ $\left.42^{\circ} 26^{\prime} 49.54^{\prime \prime} \mathrm{W}\right)$, Nova Friburgo, state of Rio de Janeiro. Presumably, the eggs hatch into non-feeding tadpoles, as in other members of the genus. This assumption is based on the large 

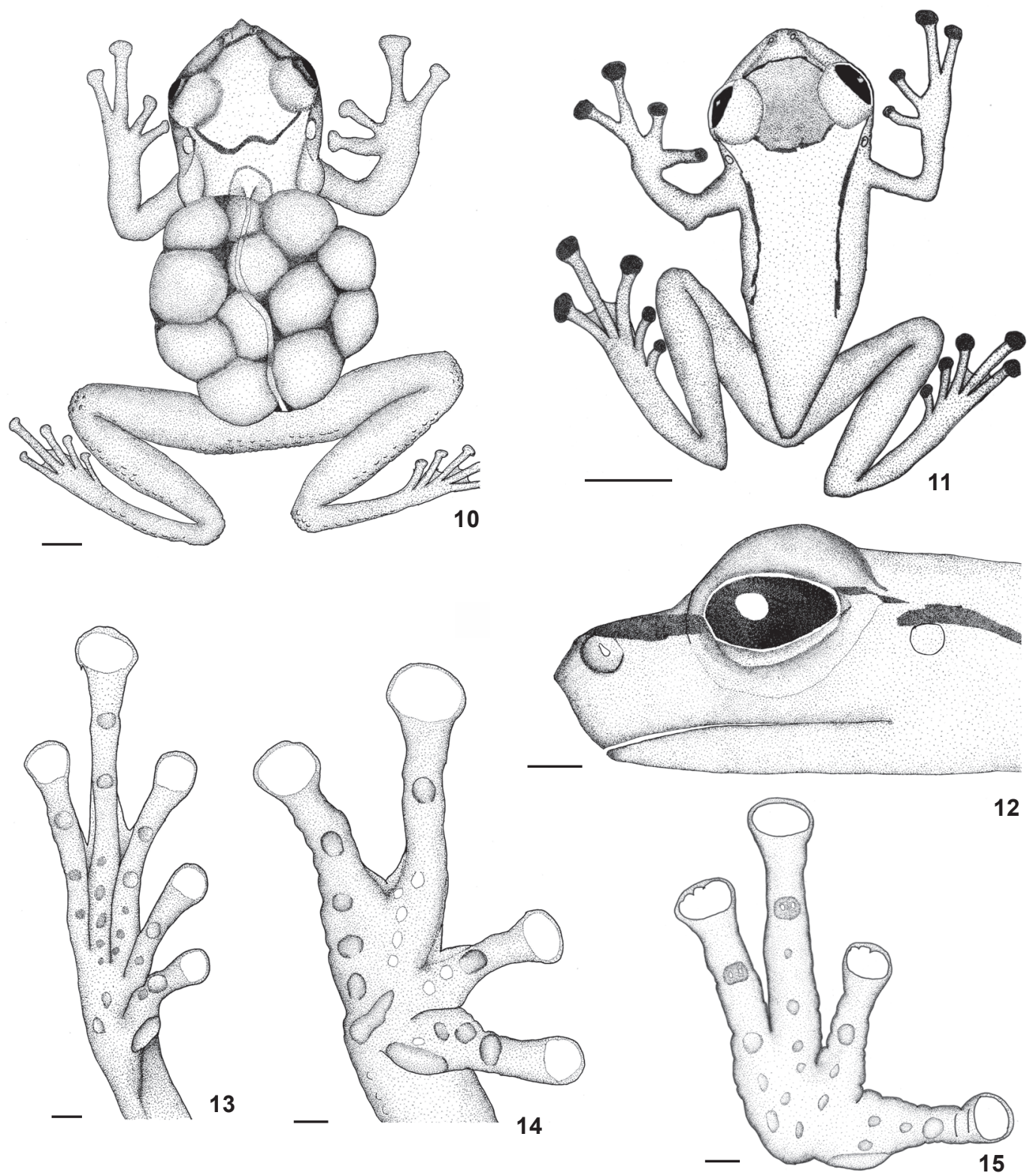

Figures 10-15. Fritziana ulei female, ZUFRJ 13337 (10, 12, 13 and 14); F. ulei male, MZUSP A-128089 (11 and 13): (10) dorsal view, note the eggs arrangement; (11) dorsal view; (12) lateral view of the head; (13) ventral view of right foot; (14) ventral view of right hand; (15) ventral view of right hand of Fritziana fissilis, note the bifid shape in the subarticular tubercles on Fingers III and IV. Scale bars: $1 \mathrm{~mm}$.

yolk amount found in the eggs of the female's back (ZUFRJ 13347). The advertisement call is unknown.

Distribution. Southeastern Brazil, state of Rio de Janeiro, municipalities of Resende and Nova Friburgo; state of São Paulo, municipality of São José do Barreiro, Parque Nacional da Serra da Bocaína (Fig. 16).

Etymology. The species ulei, is a patronym in honor of botanist Ernesto Ule, who collected the holotype.

\section{DISCUSSION}

The X-rays showed that F. ulei, as well as the other species from southeastern Brazil (Figs 1-4), have large nasals and consequently the spaces between their nasals, maxilla and premaxilla are small. Therefore, we place the F. ulei in the Fritziana.

MirandA-Ribeiro (1926) identified similar features between Fritziana ulei (as = Flectonotus ulei) and Flectonotus pygmaeus (e.g., 


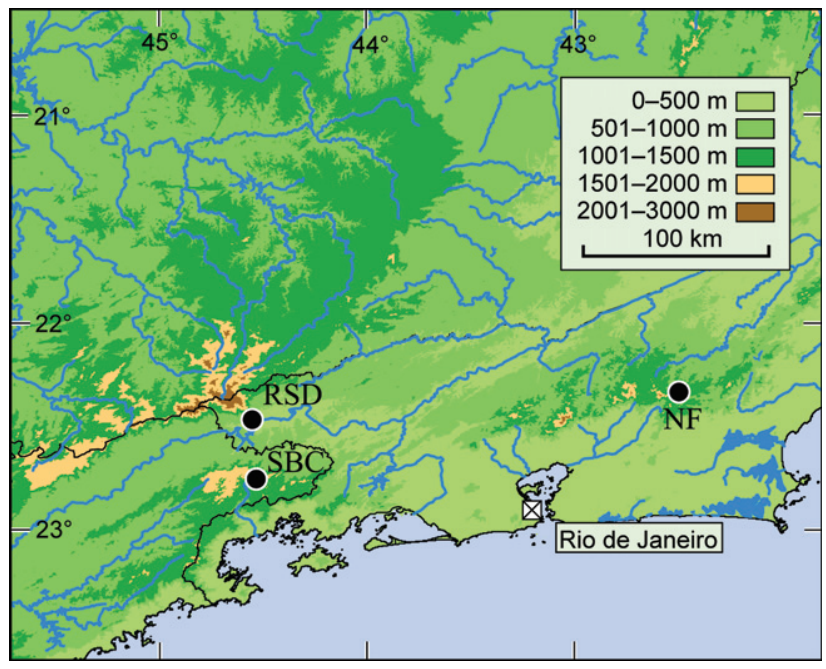

Figure 16. Geographic distribution of Fritziana ulei. Acronyms: (SBC) Parque Nacional da Serra da Bocaina, (RSD) Resende, (NF) Nova Friburgo, type-locality.

skin of the head adhered to the skull, and a few large eggs). He placed both species in the same genus, Flectonotus. Now all species from southeastern Brazil are placed in genus Fritziana (F. fissilis, F. goeldii, F. ohausi, and F. ulei), and the species from northern South America are placed in Flectonotus ( $F$. fitzgeraldi and F. pygmaeus; Duellman et al. 2011). The relative size of the nasals is an important osteological feature distinguishing Flectonotus from Fritziana (Duellman \& Gray 1983, Duellman et al. 2011).

BoKERMANN (1966) gave no reasons for considering Flectonotus ulei to be a junior synonym of $F$. fissilis. The few specimens of Fritziana ulei probably precluded the examination of this species in subsequent revisions of the genus (e.g., Duellman \& Gray 1983). Although all specimens identified by us as F. ulei are from localities where several historical collecting expeditions have taken place, Fritziana species are difficult to find in the field. During daytime they hide in bromeliads or among bamboos (Cochran 1972, Pombal \& Haddad 2005) and at night they call from inaccessible places high up in the forest.

Females of Fritziana ulei and F. fissilis are peculiar among species of the genus in having a brood pouch nearly complete (only a longitudinal slit remaining). This similarity between them may be signal that they are phylogenetically closely related. A phylogenetic study including F. ulei is lacking.

\section{Key for the identification of the species of Fritziana based on external morphology}

1. Presence of bifid subarticular tubercles on finger or toe (Fig. 15); dorsal pattern formed by interorbital dark brown hourglass/trapezoid-shaped mark, extending to the sacral region F. fissilis
1 '. Tubercles not bifid, both subarticular and supranumerary, on fingers and toes (Fig. 14); dorsal pattern not hourglass/ trapezoid-shaped mark, not extending to sacral region . 2

2. Tympanum diameter equal to, or greater than, width of disc on third finger (TYD/DD3 $\geqslant 1)$; interorbital a brown hourglass-shaped mark, extending to mid-length of body; dark brown half-moon-shaped spot, in sacral region; median transverse dark brown stripes on thighs, shanks, and feet... F. goeldii

2 '. Tympanum diameter equal to, or smaller than, width of disc on third finger; interorbital brown hourglass-shaped mark absent; dark brown half-moon-shaped spot in sacral region, absent; median transverse dark brown stripe absent or not crossing thighs and feet 3

3. Marbled dorsal and lateral pattern; throat and/or chest with brown spots; interorbital brown inverted triangle-shaped mark, with two stripes, (long and divergent, extending to sacral region; short and divergent; or short and fused); brooding females with dorsolateral folds only bordering eggs, leaving them exposed dorsally F. ohausi

3'. Without marbled dorsal and lateral pattern; throat and/or chest beige; interorbital bronze pentagon/hexagon-shaped mark delimited by a heavy black line; brooding females with dorsolateral folds extending dorsally, enclosing eggs, with median longitudinal slit; eggs in arranged symmetrically in rosette shape (Figs 5, 9, 10) F. ulei

\section{ACKNOWLEDGMENTS}

We thank D. Bastos and C. de Luna-Dias for providing photos of Fritziana ulei (holotype) F. ulei in life, respectively; Departamento de Vertebrados, Museu Nacional for permission to use the x-ray machine. We also thank A.M.P. Telles Carvalhoe-Silva, J.P. Pombal Jr, and H. Zaher for allowing access to the collections in the UNIRIO, MNRJ, and MZUSP, respectively; and I. Nunes and J.P. Pombal Jr for the helpful and detailed reviews. The Instituto Chico Mendes de Conservação da Biodiversidade (ICMBio) for providing authorization for scientific study, number: 28223-1, CAPES, CNPq and FAPERJ for providing scholarships.

\section{LITERATURE CITED}

Boettger, O. 1893. Reptilien und Batrachier aus Venezuela. Abhandlungen der Senckenbergischen Naturforschenden Gesellschaft 1893: 35-42.

BoKermanN, W.C.A. 1950. Redescrição e novo nome generico para Coelonotus fissilis Mir.-Rib. 1920. Papéis Avulsos do Departamento de Zoologia 9: 215-222.

BoKerMANN, W.C.A. 1966. Lista Anotada das Localidades-Tipo de Anfíbios Brasileiros. Serviço de documentação - RUSP, 183p. 
Boulenger, G.A. 1895. Third report on additions to the batrachian collection in the Natural History Museum. Proceedings of the Zoological Society of London 1894: 640-646.

Cochran, D.M. 1972. Living Amphibians of the World. Doubleday, 199p.

Duellman, W.E. 1970. Hylid Frogs of Middle America. Lawrence, Monograph of the Museum of Natural History, The University of Kansas, 753p.

Duellman, W.E. \& P. Gray. 1983. Developmental Biology and Systematics of the Egg-Brooding Hylid Frogs, Genera Flectonotus and Fritziana. Herpetologica 39 (4): 333-359.

Duellman, W.E.; K.H. Jungfer \& D.C. Blackburn. 2011. The phylogenetic relationship of geographically separated "Flectonotus" (Anura: Hemiphractidae), as revealed by molecular, behavioral, and morphological data. Phyllomedusa 10: $15-29$.

Heyer, W.R.; A.S. Rand; C.A.G. Cruz; O.L. Peixoto \& C.E. Nelson. 1990. Frogs of Boracéia. Arquivos de Zoologia São Paulo 31: 231-410.

Lutz, B. 1954. Anfíbios anuros do Distrito Federal. Memórias do Instituto Oswaldo Cruz 52: 155-238.

Mello-Leitão, C. DE. 1937. Zoo-geografia do Brasil. Ser. 5A. Brasiliana 77: 1-417.

Miranda-Ribeiro, A. 1920. As Hylas coelonotas do Museo Paulista. Revista do Museu Paulista 12: 321-328.

Miranda-Ribeiro, A. 1926. Notas para servirem ao estudo dos gymnobatrachios (Anura) brasileiros. Archivos do Museu Nacional do Rio de Janeiro 27: 1-227.
MYeRs, C.W. \& W.E. DUellman. 1982. A new species of Hyla from Cerro Colorado, and other tree-frog records and geographical notes from Western Panama. American Museum Novitiates 2752: 1-32.

Napoli, M.F. \& U. Caramaschi. 1998. Duas novas espécies de Hyla Laurenti, 1768 do Brasil central afins de H. tritaeniata Bokermann, 1965 (Amphibia, Anura, Hylidae). Boletim do Museu Nacional (N.S.) Zoologia 391: 1-12.

Parker, H.W. 1934. Some frogs and toads of Trinidad. Tropical Agriculture (Trinidad) 11: 123-125.

Pombal JR, J.P. \& C.F.B. Haddad. 2005. Estratégias e modos reprodutivos de anuros (Amphibia) em uma poça permanente na Serra de Paranapiacaba, sudeste do Brasil. Papéis Avulsos de Zoologia 45 (15): 201-213.

SAVAGE, J.M. \& W.R. HEYER. 1967. Variation and distribution in tree frogs genus Phyllomedusa in Costa Rica, Central America. Beitrage Zur Neotropischen Fauna 5 (2): 111-131.

Targino, M. \& S.P. Carvalho-e-Silva. 2008. Redescrição de Ischnocnema holti (Amphibia: Anura: Brachycephalidae). Revista Brasileira de Zoologia 25 (4): 716-723. doi: 10.1590/S0101-81752008000400017

Wandolleck, B. 1907. Einige neue und weniger bekannte Batrachier von Brazilien. Abhandlungen und Berlchte des KSnigllchen Zoologlsrhen und AnthropologischEthnographischen Museums zu Dresden 11: 1-15.

Weygoldt, P. \& S.P. Carvalho-e-Silva. 1991. Observations on mating, oviposition, egg sac formation and development in the egg-brooding frog, Fritziana goeldii. AmphibiaReptilia 12: 67-80.

Appendix 1. Specimens examined.

Fritziana goeldii, BrazIL, Espírito Santo: Santa Teresa, ZUFRJ 1361, 1362; Rio de Janeiro: Cachoeiras de Macacu (Reserva Ecológica de Guapiaçu, REGUA), ZUFRJ 8908, 8909, 10304; Caxias, ZUFRJ 11143; Guapimirim, ZUFRJ 3285; Teresópolis (Nova Friburgo Road), ZUFRJ: 13064-13067; Mangaratiba (Reserva Ecológica Rio das Pedras, RERP), UNIRIO 337, 3878; Nova Iguaçu, ZUFRJ 4991; Rio de Janeiro, ZUFRJ 4, 132, 1523, 1749, 6734; Teresópolis, ZUFRJ 9494-9497; (Parque Nacional da Serra dos Órgãos, PARNASO), ZUFRJ 139, 140, 6997, 8916, 11104, 11717, 12964, 13163, 13178, 13313, 13451-13547, 13520-13522, UNIRIO 236, 528, 1898, 1903, 2006, 2126, 2155, 2194, 2195, 2344, 2528, 2538, 2609, 2893.

Fritziana ohausi, BRAZIL, Espírito Santo: Domingos Martins, ZUFRJ 6533; Rio de Janeiro: Teresópolis (Parque Nacional da Serra dos Órgãos, PARNASO), ZUFRJ 595-597, 11718, 12412-12421, 12154, 12155, 13311, 13534, 13535, 13540, UNIRIO 3720; São Paulo: Salesópolis (Reserva Ecológica da Boracéia), MZUSP 26525, 26526, 31219, 31221, 31223, 31225, 31227, 31228, 31229, 31230, 31231, 31234, 31239, 31242, 31243, 31246.

Fritziana fissilis, Brazil, Espírito Santo: Domingos Martins, ZUFRJ 2016, 2017; Rio de Janeiro: Teresópolis (Parque Nacional da Serra dos Órgãos, PARNASO), ZUFRJ 145, 8917, 8935, 9662, 9663, UNIRIO 2344, 3719, 3721, 3725; (Vale da Revolta, Parque Estadual dos três picos) ZUFRJ 3923; São Paulo: Nova Friburgo, ZUFRJ 13346, MZUSP 128079-128081; (Serra do Macaé), MZUSP 30 (lectotype), 55691 (paralectotype), 55692 (paralectotype); Salesópolis (Reserva Ecológica da Boracéia), MZUSP 32060-32062; Ubatuba (Parque Nacional da Serra da Bocaína), MZUSP 79964, A-103684, A-103700, A-103702, A-103704, A-103730, A-103734, A-103782.

Fritziana ulei, Brazil, Rio de Janeiro: Nova Friburgo, MNRJ 0271; Lumiar: ZUFRJ 13347; Resende, MZUSP 128088; São Paulo: Ubatuba (Parque Nacional da Serra da Bocaína) A-75903, A-75844, A-128089.

Submitted: 23.XII.2013; Accepted: 06.VII.2014.

Editorial responsibility: Mauricio O. Moura

ZOOLOGIA 31 (4): 393-399, August, 2014 